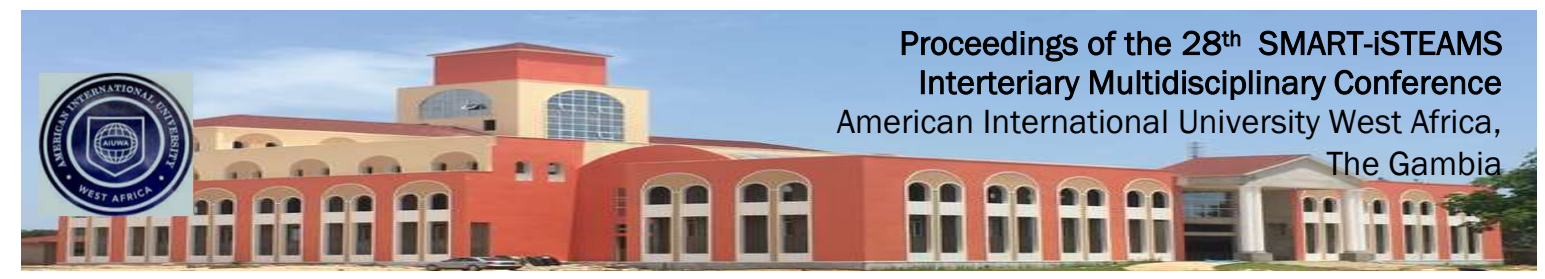

Full Research Paper

\title{
Challenges of Autonomy on Effective Local Government in Nigeria
}

Aderogba, Ademola

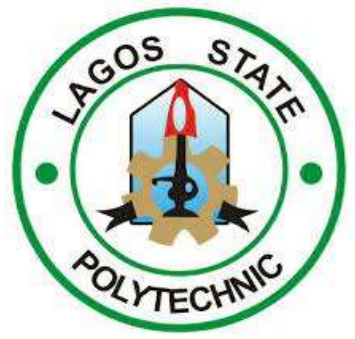

Dept of General Studies Lagos State Polytechnic, Ikorodu

Lagos State, Nigeria

E-mail:

molaaderogba2019@gmail.com

\begin{abstract}
The focus of this study is to examine the relationship between autonomy and effectiveness of local government in Nigeria. The administrative structure for local governance has always existed in one form or the other since colonial period. However, the poser is how autonomous are they as a unit of government and to what extent are they effective. This study relying on available secondary data, adduced that local governments have constitutional responsibilities, its autonomy is greatly eroded by other higher tier governments, and that lack of autonomy impedes its effectiveness. Way forward suggested include, constitutional reforms, limited role for both state and federal governments and financial autonomy for effectiveness.
\end{abstract}

Keywords: Local government, Autonomy, Effectiveness, Efficient-service, Decentralization

Proceedings Reference Format

Aderogba, A. (2021): Challenges of Autonomy on Effective Local Government in Nigeria. Proceedings of the 28th iSTEAMS Intertertiary Multidisciplinary Conference. American International University West Africa, The Gambia. October, 2021. Pp 217-228 www.isteams.net/gambia2021.

DOI - https://doi.org/ 10.22624/AIMS/iSTEAMS-2021/V28P18x 


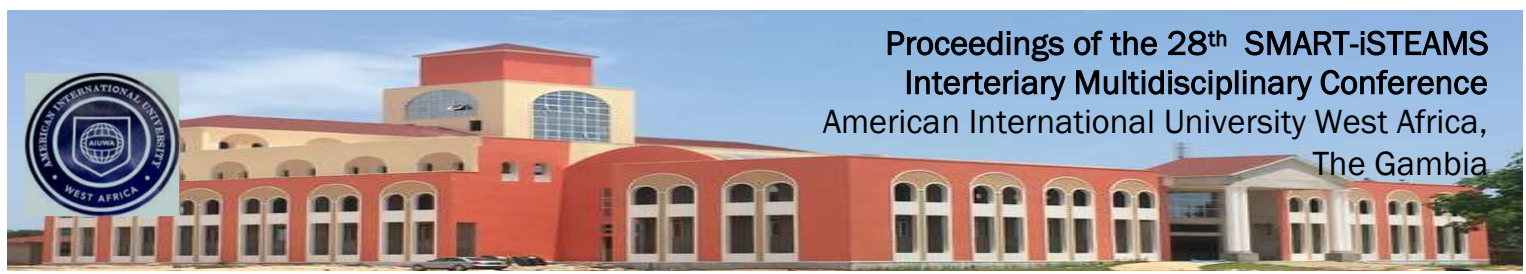

\section{INTRODUCTION}

Federalism as a system of government is commonly adopted by states because of its essentials and peculiarities by large countries with diversities in terms of socio-cultural and geographical spread. The preference stems from its recognition of multi levels or multi units structure of government, usually referred to as decentralized structure. This is a prerequisite for grassroots governance by establishing the level of government that can attend to developmental needs of the grassroots. Nigeria experience attests to this, but the extent to which this rationale is achieved is controversial.

There are many positions adduced by researchers, but one interesting area which is of concern to this paper is the question of autonomy. Federal constitution by its nature grants some level of autonomy to all the components of the federation for effectiveness. Although there is provision for intergovernmental checks and balances, the questions are: what are the constitutional provision for autonomy, to what extent are these provisions constraining the autonomy of local government, and how has this lack of autonomy hinders the effectiveness of local government in Nigeria? Therefore, this paper intends to examine these posers. The framework of this paper is as follows: theoretical framework, conceptual explanations, rationales for creation of local government, historical background of local government autonomy in Nigeria, factors constraining the autonomy of local government, Consequences of lack of autonomy and way forward for an effective autonomy that can support constitutional roles of local government in Nigeria.

\subsection{Theoretical Framework}

There are various theories relevant to the study of local government autonomy; nevertheless this paper would explore the efficiency-services theoretical framework. The fundamental of this theory is that the main purpose of local government is to provide services peculiar to the local people. The proponents of this perspective assert that local government is an efficient agent for providing these services that are local in character. To them the extent to which local governments provide these services is determined by its efficiency (Ola, 2007). Local government easily and quickly decides on policy, issues are judiciously resolved because the targets of decisions are nearer for consultation and responses. There are benefits in rendering peculiar small scale services, attending to small number of problems, for a smaller unit of nation and efficient and effective solution to the problems by local government (Kafle and Karkee, 2003)

Proponents also agree that local government exists basically to propagate efficient-service delivery and this determine how their power, resources and time would be managed. Ibietan and Ndukwe (2014) while interrogating the relevance of efficiency services theory to the Nigerian local government system opines that the fourth schedule of the 1999 constitution of the Federal Republic of Nigeria contains the functions expected from Local Government Councils, which were categorized into ; basic, extractive, regulative, educative and protective functions. They concludes that though this theory represent ideals, it did not justify the prevailing situation of local governments in Nigeria in terms of being efficient agent for providing services that are local in character 


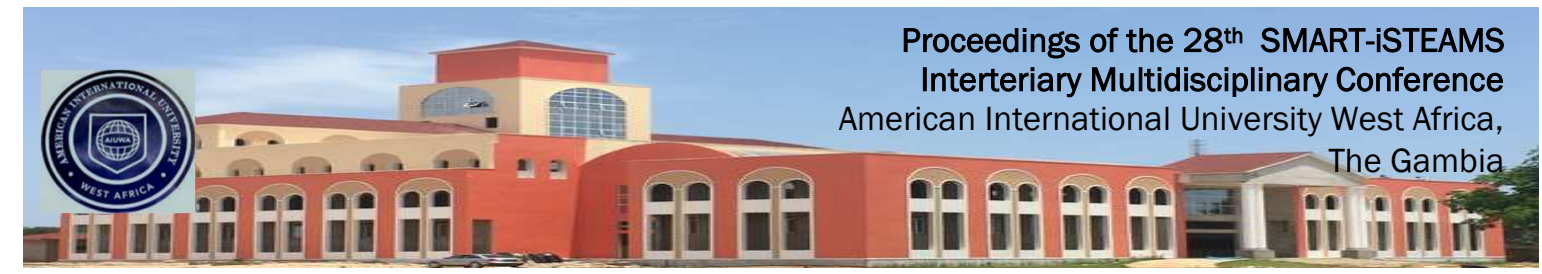

\subsection{Conceptual Explanations}

Local Government: Two basic classifications of definitions of local government can be deduced from literature. It is either on the basis of various levels of government in which administrative and political decentralization are determinants or by certain identified characteristics. According to the United Nations Office for Public Administration, local government is a political subdivision of a federation, established by law and granted substantial control of affairs within its jurisdiction, including the powers to impose levies or organize the people for prescribed purposes, with its own elected governing body. Federal Government of Nigeria Guideline on the local government reform of 1976 defined local government as: Government at the local level in which there is a representative councils constituted by law and granted specific powers, within defined geographical areas over local affairs.

Bello-Imam (2002) describes local government as a public sector organization with specific functions, responsibilities, administrative structure and financial arrangements for an effective organizational management and performance. Bryne (1994) defined local government as a selfgovernment which entails the administration of public affairs in each local area by constituted representatives within the supervision of the central government.

In a federal system of government, autonomy entails that each government tier enjoys a separate existence and independence from the control of other government tiers, hence Local government autonomy implies that a local government is expected to act independently by exercising its authority in the conduct of its affairs. It also implies that the local governments possess the power to take decision as prescribed by enabling law without undue external influence and authorities like the state or federal government (Ugwuanyi, et al, 2016).

Imhanlahimi and Ikeanyibe (2009) are of the view that local government councils should be granted adequate autonomy, rather than absolute autonomy. This refers to the autonomy where there is relative separation of central and local spheres of government on one hand, and monitoring by the central government the activities of local authorities, without interfering in its core domain, on the other hand. This is what they refer to as the relative or adequate autonomy. It is the freedom granted local governments to exercise authority within the dictates of law or constitution, to enable them discharge legally the constitutionally assigned responsibilities, without undue interference or restraint from within or higher authority.

The term local government autonomy connotes local self government or grassroots democracy. It connotes local government management with its own authority and freedom to develop policy direction and pursue its development plan without external directives (Amah, 2018). Local autonomy is possession of legal identity and freedom or independence on clearly defined issues and areas from other levels of government. Local governments, by the principles of their creation, are expected to exercise the political and administrative, as well as financial autonomy to enable them operate effectively as a distinct tier. Political and Administrative autonomy entails powers such as the authority to recruit and manage their own staff, while financial autonomy implies financial freedom, without any interference from any other tier of government in the process of managing the affairs of the local council (Ugwuanyi et al 2016). 


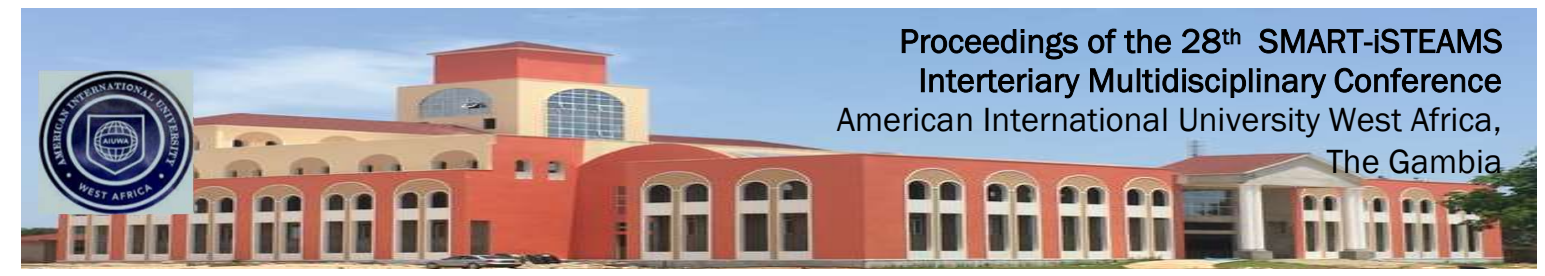

What then constitute local government autonomy? In an attempt to clarify the concept of local government autonomy, Akpan and Ekanem (2013) point out five key elements that are basic; first, the local government unit should have a legal personality distinct from the state and federal governments. Second, the local government ought to have specified powers and functions distinct from the state and federal governments. Third, the local government has to operate independently of the state and federal governments. That means that the local government is not an appendage or field office of the state or federal government. Fourth, local government ought to have the ability to make its own laws, rules and regulations. Fifth, local government should have the ability to formulate and execute its own policies and the right to recruit, promote, develop and discipline its own staff.

For Amah (2018), the autonomy of local government is determined by two primary criteria. The first is the freedom to formulate an integrated regional development plan, including economic, social and environmental plans and the second is the freedom to set its priority in budget expenditure. Autonomy requires not only the legal and physical existence of various organs of government like a legislative body, executive organ etc, but as an independent entity, not an appendage of another, and with an authority to conduct its affairs without undue interference .According to Jonathan Gooluck (2021) the Former Nigeria President, local government structure is presently weak and this is greatly affecting Nigeria's development.

\section{HISTORY OF LOCAL GOVERNMENT AUTONOMY IN NIGERIA}

In the colonial era, local government enjoyed a wide range of both financial and administrative autonomy. The local government system was derived from the British Whitehall model. The colonial government allowed each region to oversee the activities of local government under its jurisdiction. This means that the legal frame work for local government was provided for by each region: The Eastern region local government ordinance of 1950, the Western region local government law of 1952 and the 1954 native authority law in Northern Nigeria (Akpan \& Ekanem 2013).The post-colonial era and specifically, between 1960 and 1965, however, witnessed a decline in both the financial and administrative autonomy local governments wielded in the colonial era. This was accompanied by a decline in the responsibilities assigned to local governments in the four regions.

However, a major reform of the local government system in Nigeria was carried out under the military in 1976. Imhanlahimi, \& Ikeanyibe (2009) argue that from the colonial era up to 1975, what exist was more of local administration than local government and were an appendage of the Regional and later State governments. The reform include, setting up of representative councils, determination of population size of local governments, direct allocation of funds and review of personnel administration.Also, Nigeria adopted a unified local government administrative system and local government officially recognized as the third tier of government. The objectives of the 1976 local government reform includes ensuring that services and development activities reflect local needs and initiatives; facilitating grassroots democratic selfgovernment, and encouraging initiative and leadership potential. 


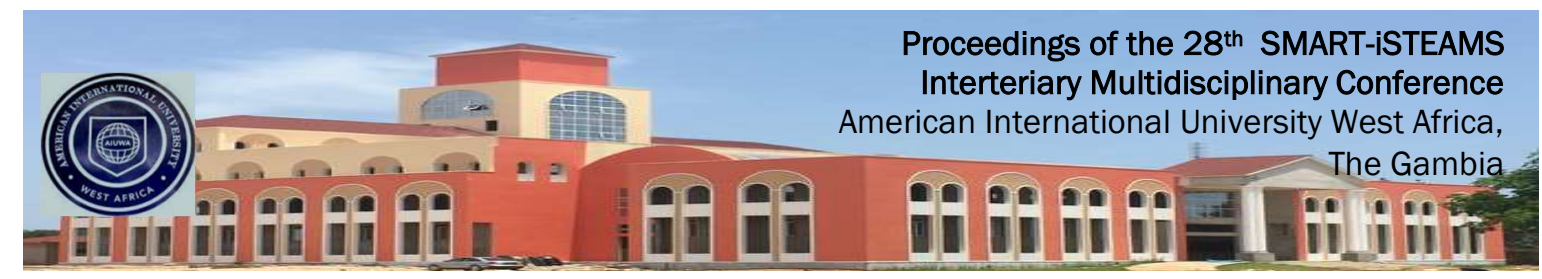

It also includes mobilizing human and material resources by involving members of the public in their local development activities; and providing a two-way channel of communication between local communities and government at the state and federal levels, (1976, reforms).

However, some public administrators have contrary opinion that the unification policy introduced by the military is at the root of interference on local government autonomy in Nigeria, because it completely eroded local government autonomy (Akpan \& Ekanem, 2013). The local government reforms initiated from 1986 to 1992 by Babangida military administration remarkably repositioned local government administration in Nigeria. The reform initiates local government autonomy by allocating fund directly to it from the federation account, abrogated the Ministry of Local Government and introduced the legislative and executive arms of government to the local government system in Nigeria (Osakede et al, 2016). Other essential innovations are; the transition programme which provides popular participation and political control of the grassroots, opportunity for new breeds in the nation's body politics, introduction of two grassroots based political parties, creation of more local governments, and the introduction of open voting system (Adeyemo, 2005).

Although 1999 Constitution attempt to address the issue of local government autonomy, through Section 7 of the 1999 Constitution which empowers the state legislature to make laws for the administrative operation of local governments within their domains; it complicates it by denying them authority to create new local governments. (Akpan \& Ekanem, 2013). While section 162(3) provided for the funding of local government by both federal and state governments, the same section also provided for disbursement of fund to local government through a local government - state's joint account to be managed by the state, thereby exposing local government to undue financial interference (Amah, 2018). Local governments have not being operating independently of both the state and federal governments since independent (Akpan \& Ekanem, 2013). The maneuvering for control of local government by state and federal governments is for their gains and not for political dividends to the grassroots. This constrains effective local government in Nigeria.

It is imperative to mention that President Buhari in an attempt to realize local government autonomy by strengthening section 7of 1999 constitution issued an executive order in May 2020 to grant financial autonomy the judiciary, legislators and local government as the third tier of government. The order directed accountant general of the federation to pay local governments their allocations directly from federation account. However, the state governments disagreed with this order and trying to frustrate this noble move (Baje,2010). 


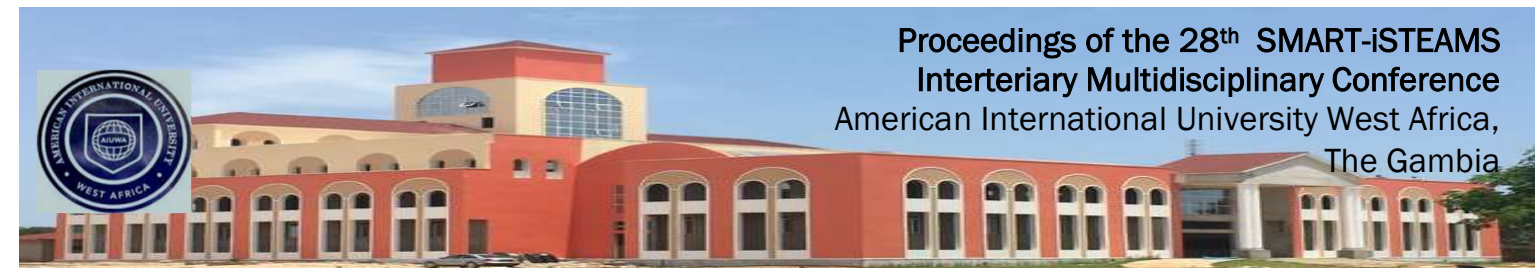

\section{BENEFITS OF LOCAL GOVERNMENT AUTONOMY}

Generally the rationale for local government autonomy centered on quest for improved welfare of people in the localities and overall national development. Specifically, the rationales are;

1. First, Administrative effectiveness and efficiency to perform assigned constitutional functions. Through decongestion of the central and sub-national government, employment of competent workforce with better condition of service and adoption of more flexible approach to responses, services are better delivered to the grassroots.

2. Second, Local government autonomy would strengthen the political structure and deepens democracy by bringing government closer to the local people thereby stimulating political participation, and fostering democratic culture through political education (Amah, 2018).

3. Third, Autonomy enhances capacity building at local level. Freedom to address the local needs would enhance both political and economic capacity acquisition. This draws the local people closer to the centre of power by increasing their capacity to control and participate in the political and economic decisions of government.

4. Fourth, It engenders even and national development. National development is predicated on the development of all its components. Development is geo-political specifics because need-felt varies. Autonomy would enable each of the councils to address its developmental priorities in terms of resources.

5. Fifth, Political stability is fostered. There are always diverse volatile interests, due to multi ethnic, religion, politics and minority issues which are usually prevalent in larger federation. Local government which enjoys autonomy and knowledge of its immediate environment would address this diversity in a way that can foster integration and unity. Local government autonomy serves the historical, cultural and linguistic aspiration of the local people (Amah, 2018).

6. Sixth, Freedom to take financial decisions and control of expenditures would boost the financial resources for local government effectiveness. Osakede et al (2016) are of the view that local government financial autonomy facilitates rural development. Ben-Caleb et al (2021) proffers four reasons for the desirability of local government financial autonomy: firstly, it would enhance delivering of services according to needs and preferences as determined by available resources. Secondly, local autonomy brings responsibility and cost-efficiency. Thirdly, local autonomy improves citizens' participation and democratic control. Fourthly, local autonomy promotes experimentation and innovation by local policy makers. 


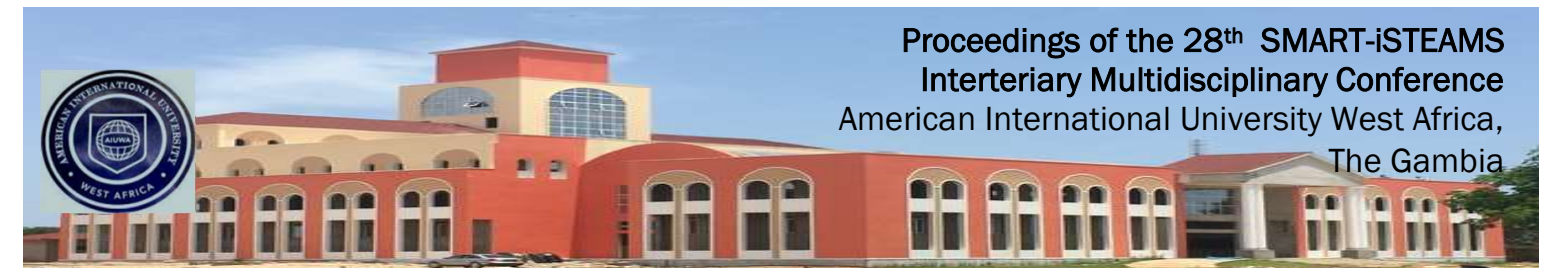

\section{FACTORS AFFECTING LOCAL GOVERNMENT AUTONOMY}

There are various aspects of autonomy and this determines the nature of factors constraining in reality the efficacy of local government autonomy in Nigeria. The observed impediments include:

\section{Structural Factors}

The structure of local government in Nigeria is determined by the constitution, which is not only written but also rigid, making amendment near impossible and inflexible, for each state and geographical area to adjust and adapt its own local council to suit its peculiarities. The provisions of 1999 constitution of the Federal Republic of Nigeria, (as amended), hinders the autonomy of local governments as an autonomous tier. The constitution was ambiguous on the delegation of authority between the states and local governments in relation to concurrent responsibilities (Doho,et al, 2018). Section 7 reads jointly with Section 8 recognized local government as a tier of government, at the same time in section 1 schedule 4; Constitution empowers the State House of Assembly to regulate it. Section 7(6) of the 1999 Constitution provides for a democratically elected Local government Council without a definite tenure unlike the State and Federal with four year tenure, thereby exposing local government to manipulations of state government. Nwabueze (1983) in Ugwu (2003) as cited in Asaju (2010), asserted that the Constitutional power to create local government, define its structure, composition and functions, resides in the State governments

\section{Political Factors}

Political autonomy of local government is eroded by granting state government power to organize local elections. State governments manipulate the election process to favour their loyalist or out rightly imposed candidates without respect for merit (Ugwuanyi et al (2016). State governments dissolve local council without any caution and illegally constitute local council caretaker committee as it pleases them. The Governor or State House of Assembly is empowered to constitute investigative panel on any local government and when they are indicted, it can attract suspension for a period not more than two months (Abah et al, 2011). Finding by the year 2015reveals that, the practice of Care-taker Committee was gradually becoming a norm because out of the 774 local government areas in Nigeria, less than 70 percent were governed by democratically elected officials (The Sun, 2015). Furthermore, political prebendalism and clientelism hinders independent decision making by elected political officials at local level and where they vacillates it provoke political instability.

\section{Administrative Factors}

Interference in local governments' administrative autonomy is caused by some provisions of 1999 constitution, practice and policies of state governments, and unethical practices of employees. Indisputably, there is ambiguity in the constitutional provision regarding delegation of authority between the states and local governments as it affects concurrent responsibilities thereby hampering administrative effectiveness of the latter (Doho et al, 2018). Constitution provided for establishment of the State Local Government Service Commission to regulate administrative and personnel activities of local government, which is usually manipulated by the state to interfere in their administrative autonomy. The result is overpopulation of personnel with incompetent political associates and lack of independent positive decisions on rural 


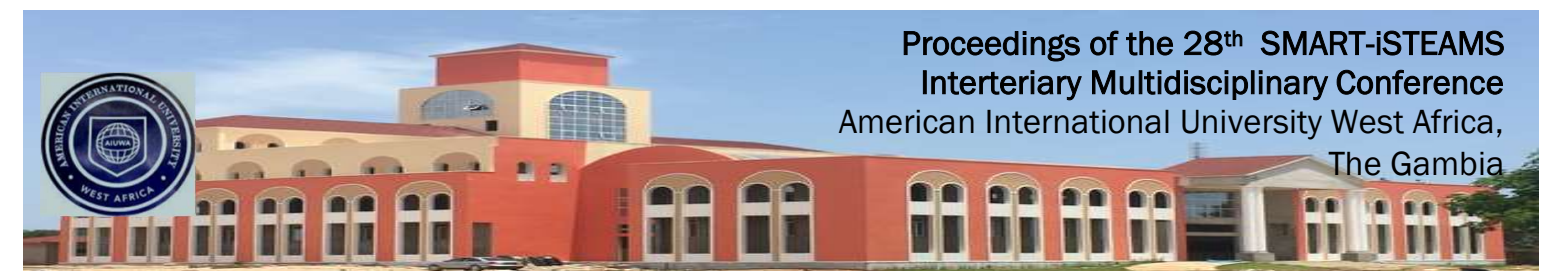

development. There are policies and practices constraining the administrative autonomy by creating institutions like, Ministry of Local Government, Local Government Service Commission, Office of Special Adviser to the President on local government matters, Office of the Special Adviser to the Governor on local government Affairs, the Senate and House of Representative Committees on local government affairs, and the State Houses of Assembly Committee on local government matters (Akpan \& Ekanem, 2013). All these bodies either directly or otherwise interfere in the process of overseeing the activities of local government. Also added to these are unethical official practices like corruption, petty politics, and personal interest overriding official interest.

Financial Factors

Section 162, Paragraph 6, of 1999 constitution provided for the establishment and operation of State Local Government Joint Account. Ugwuanyi et al (2016) observe that state governments have turned the State Joint Local Government Account into an instrument to manipulate and control the local governments. State Governors manipulates local governments to engage in joint projects that either have no impacts on the people of the areas or eventually abandoned, as either a political patronage or for fund diversion (Doho,2018). In year 2010 alone, 31 out of the 36 states governors tampered with local government funds through the instrumentality of State Joint Local Government Account (Ukiwo, 2010).

\section{CONSEQUENCES OF LACK OF LOCAL GOVERNMENT AUTONOMY IN NIGERIA}

Local governments exist to provide peculiar services economically and effectively to the rural communities. Unfortunately, due to their parochial interests and political agenda, the federal and state governments exercise undue influence and control over local authorities, thereby hindering the effectiveness of local governments. In sampling 645 newspapers, Imahanlahimi and Ikeanyibe (2009) found that local governments were severely criticized for poor development efforts in their localities due to interference of higher tiers domineering governments.

Inadequate fund and poor funding of development projects is also rooted in the lack of financial autonomy of local governments (Anayochukwul \& Ani, 2021). Wada and Aminu, (2014), noted that manipulation of state- local-government joint account by the state governments is responsible for poor performance of local government in terms of its constitutional responsibilities. For instance, in Enugu state under the regime of Governor Chimaroke Nnamani, between 1999 and 2007, the control of the State Joint Local Government Account by the state government was so total that sometimes it was difficult to pay salaries of the staff and execute infrastructural development projects (Ugwuanyi et al, 2016).

The interference in the administrative and Political affairs of the local governments affects the effectiveness of local governments. Osakede, ljimakinwa and Adesanya (2016) found that lack of an efficient and effective service delivery to rural dwellers is as a result of interference and nepotism of the state government which encourages corruption among the officials of the local governments. 


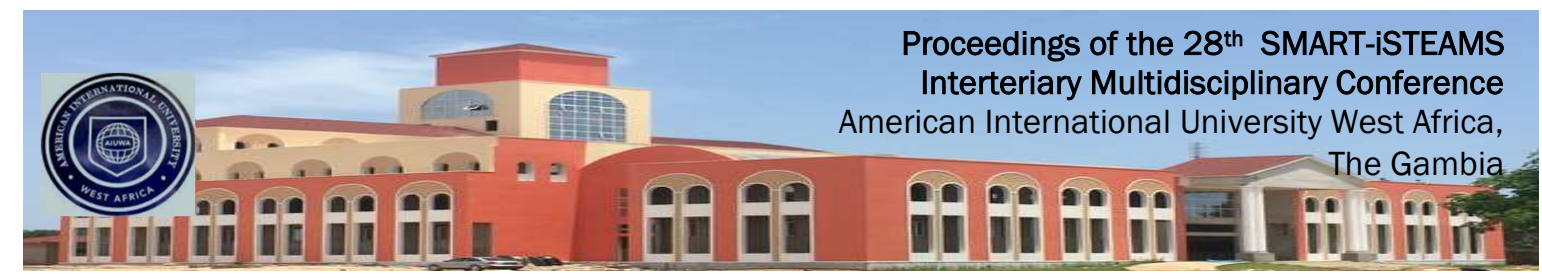

The lack of autonomy of local governments also hinders democratic consolidation in the federation. Akpan and Ekpanem (2013) noted that local governments suffer from the manipulation of political process and the control of political recruitment at the leadership level. The Federal and State governments often disregard the elective representative principles and constitutionally guaranteed existence of local governments (LGs) (Imhanlami \& Ikeanyibe, 2009). Since inception of the fourth republic in 1999, LGs have either been scrapped by higher level governments or their democratic elections manipulated, at times the entire elected councils were dissolved without due process, and replaced with hand-picked bodies such as Development Committees, Sole Administrators and Caretaker Committees. Instance was the case of Abia State in 2006 in which former Governor, Orji Uzor Kalu, pronounced the dissolution of 148 elected Local Government officials. The action was overruled by the Supreme Court which described it as illegal and "official recklessness" (Salaam, 2016). Also, this undemocratic practice disenfranchises the citizens at the grassroots, thereby creating grassroots political apathy (Doho et al, 2018).

\section{WAYS TO PROMOTE LOCAL GOVERNMENT AUTONOMY}

For any meaningful development to take place at the local level, local governments need to enjoy political, administrative and financial autonomy without undue interference from both the federal and state governments. The following suggestions would assist the process:

\section{Limited Role for State and Federal Governments}

The role of the Federal and State Governments should be limited to supervision and monitoring of local government projects and programmes in order to maintain standard. This would ensure prudence, accountability, and effective Service delivery at the local level.

\section{Democratic Consolidation}

Imhanlahimi \& Ikeanyibe (2009) asserts that Democratic consolidation and reduced corruption are essential to the operation of an autonomous local government. Democratic consolidation through open and participatory process, and guaranteed rule of law would assist in entrenching the constitutional provisions on local governments. Ugwuanyi et al (2016) recommend constitutional reforms that can guaranty political autonomy through mandatory democratic election conducted by Independent National Electoral Commission (INEC) and not State Independent Electoral Commission (SIEC), and vesting Executive powers on chairmen and supervisory councilors on matters that are local in nature.

\section{Constitutional Reforms}

There are some conflicting provisions of the 1999 Constitution as identified above that needed review to strengthen local government autonomy, such as provisions on joint accounts, local government elections and staffing. Osakede at al (2016) recommend direct payment of allocation to the Local government from the federation account and not through the state governments. 


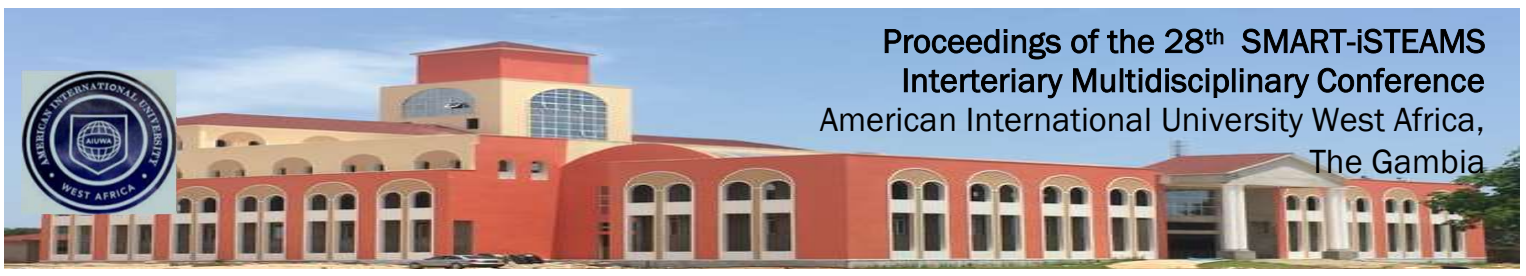

\section{Anti Corruption}

Corruption in Nigerian local government system should be effectively and dispassionately addressed by appropriate institutions, like the ICPC and EFCC, and any infraction should properly prosecuted by the Court of law without any interference.

\section{Strengthening Administrative Efficiency}

Eeffective and efficient administration is required for productive autonomy. However, it can only be achieved through an independent competitive employment processes managed by the local government and not state government. The structure, finance, establishment, composition and functions of local government councils should not be vested in state house of assembly but the constitution. Ben-Caleb et al (2021) agree that granting financial autonomy to local government areas will engender rural development. However, there must be provision for control mechanism to ensure budget discipline and prevents financial mismanagement. 


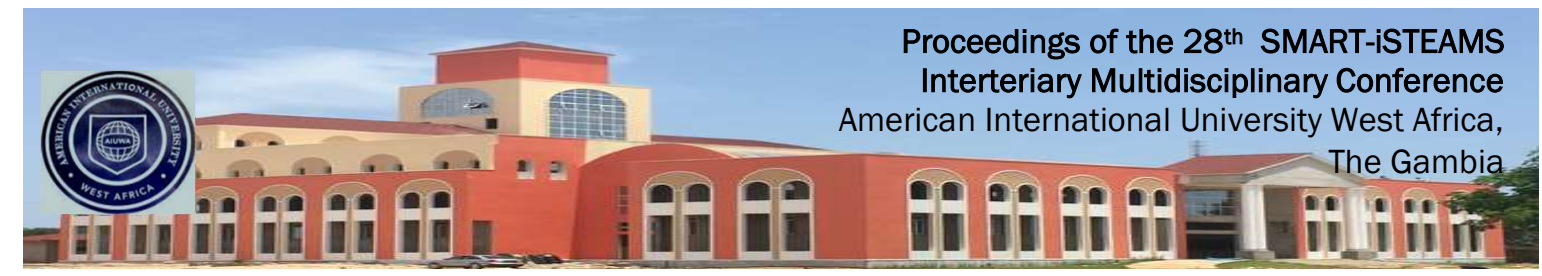

\section{REFERENCES}

1. Akpan, F. \& Ekanem, O. (2013), “The Politics of Local Government Autonomy in Nigeria Reloaded", EuropeanScientific Journal, December 2013 edition vol.9, No.35, pp 193205, ISSN: 1857 - 7881.

2. Anayochukwu GI, Ani VA (2021) Local Government Autonomy in Nigeria: Its Problems and Prospects. Review Pub Administration Manag. 9:300. https://www.longdom.org/open-access/local-government-autonomy-in-nigeria-itsproblems-and-prospects.pdf

3. Amah, E. I. (2018). "Devolution of Power to Local Government: Appraising Local Government Autonomy underNigerian Federation", Beijing Law Review, 9, pp 275-293

4. Baje, O.A.(2021), President Buhari and local government autonomy. The Guardian Newspapers, Lagos, Nigeria, 23 July 2021 https://guardian.ng/opinion/presidentbuhari-and-local-govt-autonomy/.

5. Bello-Imam, I.B (2002); Local government finance in Nigeria; Ibadan Jodad publishers

6. Ben-Caleb, E., Madugba, J. U., Ajibode, O. O. \& Ben-Caleb, J. O. (2021). "Financial Autonomy and Rural Development in Ogun State, Nigeria: A Stakeholder's Perspective", Public Administration Issues, no 5 (Special Issue I, electronic edition), pp. 41-55 (in English). DOI: 10.17323/1999-5431-2021-0-5-41-55.

7. Doho, A. W., Ahmed, A., \& Umar, A. (2018). 'Local Government Autonomy In Nigeria: Struggles And Challenges". Advances in Social Sciences Research Journal, 5(5) 44-51. Dol:10.14738/assrj.55.4498.

8. Federal Republic of Nigeria, 1976 Local Government Reforms guidelines, Lagos, Federal Ministry of Information.

9. Imhanlahimi, J. \& Ikeanyibe, M. (2009), "Local Government Autonomy and Development of Localities in Nigeria: Issues, Problems and Suggestions", Global Journal of Social Sciences Vol 8, No. 2, pp 13-30.

10. Jide Ibietan, and Peter Ndukwe (2014) 'Local Government Administration in Nigeria and Community Development: The Efficiency Services Interrogation". International Journal of Management Sciences' Vol. 3, No. 10, 2014, 751-764 Research Academy of Social Sciences http://www.rassweb.com.

11. Jonathan,G.E.(2021). LGAs must be Autonomous, Generate Revenue. Vanguard Newspaper, Lagos, Nigeria, April 30.

12. Kafle, S. \& Karke, K. (2003). "Towards Ideal Local Government: Strengthening Participatory Development. Unpublished Memoir.

13. Nwabueze (1983) in Ugwu (2003) in Asaju,k (2010) International Journal of Advanced Legal Studies and Governance Vol. 1 No.1

14. Abah;E.O. Shija;M.D. Ejeh; A.J.(Esq.) and A.T. Zever (2011), The Problems of Autonomy And Control In Local Government In Nigeria. The Nigerian Journal of Research and Production, Volume 18, No 2.

15. Ola, R.F (2007), "Local Government Theory \& Practice: An Examination of Modernization Efforts in Three Decades of Nigerian Local Government (1975 -2003)" in Development Agenda of the Nigerian State, eds. AA Agagu \& RF Ola, Lord Keynes Publishing, Akure, pp.. 205-215.

16. Osakede, K. Ijimakinwa S. \& Adesanya T. (2016), “Local Government Financial Autonomy in Nigeria: An Empirical 


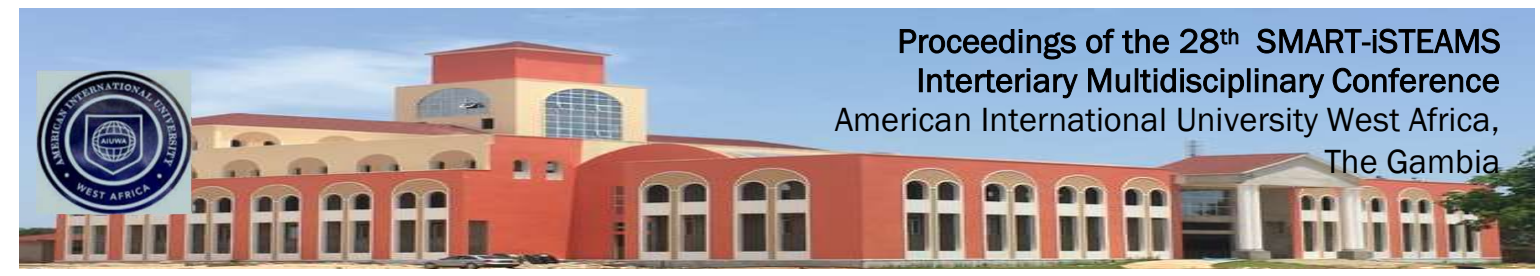

17. Analysis", Arabian Journal of Business and Management Review, Kuwait Chapter Vol. 5, No.11, pp 24-37.

18. The 1976 Local Government Guidelines, Federal Republic of Nigeria

19. The Sun (2015) ed. "“Toying with Local Government” Tuesday, 8th Dec.

20. Ugwuanyi, B., Offor, M., Nweze, O. (2016), "Local Government Autonomy in Nigerian Federal System: State Intervention and the Implications for National Development", NGJournal of Social Development, Vol 5, No. 2, pp 153-163 ISSN: 0189-5958

21. Ukiwo, U. (2010) "Creation of Local Government Areas and Ethnic Conflicts in Nigeria: The Case of Warri, Delta State". The Hague: Korimkilijice The Swart.

22. United Nations (1976), Office for Public Administration.

23. Wada, E. \& Aminu, I. (2014) "The Imperative of Local Government Autonomy and Intergovernmental Relation in Nigeria", International Journal of Public Administration and Management Research (IJPAMR) Vol 2, No. 3, pp 74-83 